\title{
PINTAIL PARASITIZING SNOW GOOSE NEST
}

R. R. CAMPBELL, Dept. of Zoology, University of Guelph, Guelph, Ontario and E. BOORMAN, Dept. of Biology, Queen's University, Kingston, Ontario

On May 27, 1975, an active Snow Goose (Anser caerulescens caerulescens) nest containing two Snow Goose eggs and one Pintail (Anas acuta) egg was found on the La Pérouse Bay Snow Goose colony. located $30 \mathrm{~km}$ east of Churchill, Manitoba. The nest was situated near the edge of a small ( 0.5 ha) delta island in the Norton River, this being one of the last vegetated islands of the foreshore flats. Lime grass (Elymus arenarius mollis) and willow (Salix sp.) were the predominant vegetation.

The nest was examined daily for three days after the initial observation, and by May 30, 1975, contained four Snow Goose eggs in addition to the Pintail egg. Subsequent observations at intervals of two days until June 7 , 1975, revealed that all five eggs were being incubated (incubation commenced May 29 or 30) and that the male Snow Goose was defending the nest territory. The nest was examined intermittently from June 7 to 22, 1975, when we found evidence that the Pintail egg had hatched and that the remaining three eggs had been abandoned (one egg had been collected June 7, 1975, as part of a research project). Examination of the remaining eggs indicated that all were fertile and very close to hatching when abandoned. On June 23, the male and female Snow Geese were observed with the duckling in the vicinity of the abandoned nest. No further sightings were made of this "family."

Four other Snow Goose nests were situated on the island, the closest being some $20 \mathrm{~m}$ distant. No eggs of other species were found in these or, with one exception, (see below), in any of the other Snow Goose nests studier on the colony. No Pintail nests wer found in the immediate vicinit) although others were found on island further from the coast on a brackisf lagoon. These were smaller island with more willow cover and such nest were usually hidden among the willows.

One other Snow Goose nest con tained one Common Eider (Somateri mollisima sedentaria) egg. Also on Canada Coose (Branta canadensi interior) nest was found containin four Canada Coose eggs, one Common Eider egg and a Snow Goose egg. Th nests were within $10 \mathrm{~m}$ of each othe an an eider nest was discovered withil $3 \mathrm{~m}$ of the Canada nest. Two othe eider nests were located about th same distance from the Snow Goos nest on an adjoining island. Willov and lime grass were the predominat vegetation. No further examination o these nests was made until late July, b which time all nests were empty. Ther was no evidence of hatching predation.

Weller cites instances of Pintail laying eggs in the nests of Canad. Geese, Mallards (Anas platyrhynchos and Redheads (Aythya americana). ${ }^{6} \mathrm{~N}$ instances of Pintails laying eggs Snow Goose nests appear to have bee reported in the literature. Dum nesting and intra-species parasitisn have been reported for both Snow Blue Geese and the Canada Coose. ${ }^{35}$ Canada Ceese have also been reporte to lay eggs in the nests of Mallards and in the nests of Osprey (Pandio haliaetus). ${ }^{4} 1$ The American (Commor Eider has layed eggs in the nests of th Herring Gull (Larus argentatus) and it 
own species. ${ }^{6}$ In the case of the eider it would not seem too surprising to find this species parasitizing nests of other species when nests are in close proximity. Fred Cooke and associates have found this to be a fairly common occurrence in the La Pérouse Bay colony (pers. comm.). Weller has indicated that of all non-obligate parasites, waterfowl (Anatidae) are most noted for laying eggs in the nests of other birds. ${ }^{6}$

We thank Murray C. Smith and Robert Milne of the University of Guelph for helpful comments on the manuscript, and Fred Cooke of Queen's University for his help and coperation on the project of which this paper is a by-product. Funds for the project were provided by Canadian Wildlife Service, Canadian National portsmen's Show, Wildlife Society and the National Research Council of Canada.

'BENT, A. C. 1925. Life histories of North American wild fowl. Part 1. U.S. Nat. Mus. Bull. 126: 244 pp.

${ }^{2}$ BOYER, R. L. and M. J. PSUJEK. 1975. Canada Goose parasitizing Mallard nest. Wilson Bull. 87(2):287.

${ }^{3} \mathrm{COOCH}$, F. G. 1961. Ecological aspects of the Snow-Blue Goose complex. Auk. 78:72-89.

${ }^{4}$ FANNIN, J. 1894. The Canada Goose and Osprey laying in the same nest. Auk. 11:332.

5PREVETT, J. P. and L. S. PREVETT, 1973. Egg retrieval by Blue Geese. Auk. 90(1):202-204.

'WELLER, M. W. 1959. Parasitic egg laying in the Redhead (Aythya americana) and other North American Anatidae. Ecol. Monogr. 29:333-365.

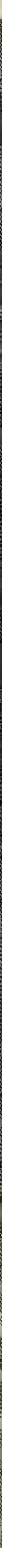

